\title{
INTERPRETASI KEBIJAKAN PEMBANGUNAN KEPARIWISATAAN INDONESIA
}

\author{
Awaludin Nugraha ${ }^{1}$, R.R. Erna Sadiarti Budiningtyas ${ }^{2}$ \\ ${ }^{1}$ Sekolah Pascasarjana, Universitas Padjadjaran, J1. Dipati Ukur 35, Bandung-40132. \\ ${ }^{2}$ Akademi Bahasa Asing St. Pignatelli, Jl. Duwet I, Karangasem, Laweyan, Surakarta-57145 \\ E-mail: awaludin.nugraha@unpad.ac.id ; sabinaerna70@gmail.com
}

\begin{abstract}
Abstrak. Kebijakan pembangunan kepariwisataan Indonesia berkembang seiring dengan perkembangan politiknya. Dua undang-undang tentang kepariwisataan, yaitu UU 9/1990 dan UU 10/2009 merupakan produk kebijakan pembangunan kepariwisataan Indonesia. Keduanya dihasilkan dalam kondisi politik yang berbeda. Tujuan kebijakan pembangunan kepariwisataan Indonesia adalah mewujudkan tujuan nasional bangsa Indonesia melalui pembangunan kepariwisataan. Tujuan nasional bangsa Indonesia tersurat dan tersirat dalam Pembukaan UUD 1945. Artikel ini bertujuan untuk memahami perkembangan paradigma kebijakan pembangunan kepariwisataan di Indonesia melalui pemaknaan terhadap UU 9/1990 dan UU 10/2009 yang dikaitkan dengan tujuan nasional bangsa Indonesia. Untuk memahami hal tersebut diperlukan interpretasi terhadap kedua kebijakan tersebut dengan mengaitkannya pada esensi Pembukaan UUD 1945. Metode penelitian yang digunakan adalah metode kepustakaan. Analisis datanya menggunakan metode hermeneutika Dilthey berupa kegiatan yang bersifat triadik terhadap ketiga sisi yang saling berhubungan dan saling berdialektik, yaitu teks kebijakan, pengalaman mental pembuatnya, dan subjek yang meginterpretasikannya. Makna teks kebijakan dipahami melalui sejarah pembuat dan pembuatannya, sedangkan subjek yang menginterpretasikannya harus memasuki jiwa zaman masa pembuatan teks. Hasil penelitian menunjukkan bahwa kebijakan pembangunan kepariwisataan tahun 1990 sejalan dengan tujuan bangsa Indonesia, karena paradigma persatuan dan kekeluargaan masih diusung oleh kebijakan itu. Kebijakan pembangunan kepariwisataan tahun 2009 mulai berbelok menjauh dari tujuan bangsa Indonesia, karena telah dibawa ke paradigma persaingan bebas yang mengabaikan aspek kekeluargaan.
\end{abstract}

Kata kunci; kebijakan pariwisata; interpretasi kebijakan; hermeneutika dilthey, sejarah pariwisata.

\section{THE INTERPRETATION OF THE INDONESIA TOURISM DEVELOPMENT POLICY}

\begin{abstract}
Indonesia's tourism development policy develops along with its political development. Two laws on tourism, namely Law 9/1990 and Law 10/2009, are products of Indonesia's tourism development policy. Both was produced under different political conditions. The objective of Indonesia's tourism development policy is to realize the national objective of the Indonesian nation through tourism development. The national objective of the Indonesian nation is explicit and implicit in the Preamble of the Indonesian Constitution (UUD 1945). This article aims to understand the development of the tourism development policy paradigm in Indonesia through the interpretation of Law 9/1990 and Law 10/2009 which is assosiated with the national objectives of the Indonesian nation. To understand this, interpretation of the two policies is needed by linking them to the essence of the Preamble to the Indonesian Constitution. The research method used is the library method. The data analysis uses Dilthey's hermeneutics method in the form of triadic activities on the three interconnected and interrelated sides, namely the policy text, the mental experience of the creator, and the subjects that interpret it. The meaning of the policy text is understood through the history of its maker and its making, while the subject who interpreted it must enter the soul of the era of the making of the text. The results showed that the 1990's tourism development policy was in line with the goals of the Indonesian nation, because the paradigm of unity and kinship was still carried by the policy. Tourism development policy in 2009 began to turn away from the goals of the Indonesian nation, because it has been brought to the paradigm of free competition which ignores the family aspect.
\end{abstract}

Key words; tourism policy, policy interpretation, dilthey's hermeneutic, tourism history.

\section{PENDAHULUAN}

Sektor pariwisata dewasa ini menjadi andalan pendapatan devisa untuk menggantikan sektor minyak bumi. Banyak pihak membangun dan mengembangkan destinasi pariwisata. Masyarakat di desa-desa pun banyak yang mengembangkan potensi desanya untuk dijadikan atraksi wisata guna menarik wisatawan (Qoriah et al, 2019; Junaid et al., 2020; Waruwu et al., 2020). Begitu pula industri pariwisata di daerah-daerah tumbuh dan berkembang. Persaingan antar pemangku kepentingan priwisata pun muncul. Tidak sedikit dari mereka yang bersaing itu saling menjatuhkan (Oktaviyanti, 2013; Damiasih dan Kusdarwati, 2016; Nisbiatin, 2018). Fenomena tersebut tidak bisa dilepaskan dari berjalannya undang-undang kepariwisataan yang menjadi kebijakan pembangunan kepariwisataan di Indonesia.

Kebijakan pembangunan kepariwisataan merupakan kebijakan publik di sektor kepariwisataan. Kebijakan publik merupakan suatu konsep dalam ilmu politik (Birkland, 2016). Dye (2012: 3) mendefinisikan kebijakan publik sebagai apapun yang dipilih pemerintah untuk dilakukan atau tidak dilakukan. Definisi Birkland (2016: 9) agak lebih menyempit daripada definisi Dye (2012: 3), yaitu suatu pernyataan pemerintah, pada tingkat apapun, tentang apa yang ingin dilakukan yang berkaitan dengan masalah publik. Pernyataan itu dapat ditemukan dalam konstitusi, undang-un- 
dang, peraturan, putusan pengadilan, atau keputusan lembaga atau pemimpin. Sehubungan hal tersebut, bentuk kebijakan publik dapat berupa undang-undang, peraturan, atau himpunan semua hukum dan peraturan yang mengatur masalah tertentu (Birkland, 2016: 10).

Definisi yang lebih sempit lagi dikemukakan Cochran et al. (2012: 2), yaitu serangkaian tindakan pemerintah yang dikoordinasikan untuk mencapai tujuan tertentu. Serangkaian tindakan itu dapat dimanifestasikan dalam bentuk undang-undang, pernyataan publik, peraturan resmi, atau pola perilaku yang diterima secara luas dan dapat dilihat oleh publik, serta implementasi dari undang-undang.

Dengan demikian, suatu kebijakan publik dapat berupa undang-undang atau peraturan-peraturan lainnya (Cochran et al., 2012; Birkland, 2016). Dalam sejarah Indonesia, terdapat dua undang-undang kepariwisataan yang pernah dibuat DPR bersama dengan pemerintah, yaitu UU 9/1990 tentang Kepariwisataan dan UU 10/2009 tentang Kepariwisataan. UU 9/1990 berlaku pada 18 Oktober 1990 sampai 16 Januari 2009, sedangkan UU 10/2009 berlaku sejak 16 Januari 2009 sampai sekarang. UU 9/1990 dibuat ketika masa Pemerintah Presiden Soeharto, sedangkan UU 10/2009 dibuat ketika masa Pemerintah Presiden Susilo Bambang Yudhoyono. Undang-undang kedua merupakan undang-undang pengganti undang-undang sebelumnya.

Adanya dua undang-undang kepariwisataan tersebut menunjukkan bahwa telah terjadi perubahan dalam kebijakan pembangunan kepariwisataan di Indonesia. Perubahan tersebut tidak boleh menyimpang dari UUD 1945, karena menurut UU 12/2011 tentang Pembentukan Peraturan Perundang-Undangan, UUD 1945 merupakan hukum dasar dalam peraturan perundang-undangan di Indonesia. Selain pada aspek hukumnya, penyimpangan itu tidak boleh terjadi juga pada aspek tujuannya, karena pada dasarnya suatu kebijakan dibuat untuk mencapai suatu tujuan. Tujuan itu adalah kehendak rakyat yang akan diwujudkan oleh pemerintah melalui kebijakan yang dibuat (Cochran et al., 2012; Birkland, 2016). Bangsa Indonesia telah menentukan tujuan membentuk negaranya. Tujuan itu tersurat dan tersirat dalam Pembukaan UUD 1945.

Kebijakan kepariwisataan itu harus dapat mengantarkan bangsa Indonesia ke tujuan tersebut. Oleh karena itu, undang-undang itu harus selaras dengan tujuan yang telah ditetapkan. Namun, apakah undang-undang kepariwisataan itu telah selaras dengan tujuan nasional bangsa Indonesia seperti yang tersurat dan tersirat dalam UUD 1945? Apakah pembuat undang-undang kepariwisataan itu telah berasaskan pada tujuan nasional bangsa Indonesia? Artikel ini bertujuan untuk memahami perkembangan paradigma kebijakan pembangunan kepariwisataan di Indonesia melalui penafsiran dan pemaknaan terhadap UU 9/1990 dan UU 10/2009 yang dikaitkan dengan tujuan nasional bangsa Indonesia.

\section{METODE}

Penelitian ini merupakan penelitian kepustakaan, sehingga metode penelitiannya pun menggunakan metode penelitian kepustakaan. Data yang didapatkan dari metode penelitian kepustakaan berupa data sekunder dan berbentuk teks (Zed, 2008). Data itu akan diinterpretasi dengan menggunakan pendekatan hermeneutika Dilthey.

Hermeneutika berasal dari kata bahasa Inggris hermeneutics, yang secara etimologis berasal dari bahasa Yunani hermeneuein, yang berarti menjelaskan, menafsirkan, atau menerjemahkan. Dalam bahasa Latin, hermeneuein diterjemahkan menjadi interpretatio (Schmidt, 2010). Sehubungan hal tersebut, Sumaryono (1999) mengartikannya secara harfiah sebagai penafsiran atau interpretasi. Tujuan dari interpretasi adalah membuat makna yang kabur, gelap, dan jauh menjadi makna yang yang jelas dan dapat dipahami sesuai dengan konteksnya (Palmer, 1980; Schmidt, 2010). Dengan begitu, maka hermeneutika adalah studi tentang pemahaman, khususnya pemahaman teks.

Dalam proses pemahaman terhadap suatu teks, terdapat tiga aspek yang terlibat, yaitu konteks pengarang, konteks teks, dan konteks pembaca. Jika jarak di antara ketiga aspek itu saling berjauhan, baik karena waktu, tempat, budaya, dan bahasa, maka teks itu menjadi sesuatu hal yang asing bagi pembacanya. Untuk mengatasi keterasingan itu diperlukan interpretasi. Suatu proses pemahaman memerlukan tiga komponen, yaitu teks, konteks, dan kontekstualisasi. Teks adalah suatu wacana tertulis. Konteks adalah pemahaman teks yang sesuai dengan maksud pembuatnya, sedangkan kontekstualisasi adalah proses memahami teks oleh penafsir dengan masuk ke jiwa pembuatnya dan jiwa zamannya dan melepaskan diri dari jiwa zaman penafsir (Palmer, 1980; Schmidt, 2010; Sumaryono, 1999).

Dalam perspektif hermeneutika Dilthey, kebijakan yang berupa teks itu merupakan ekspresi pengalaman mental pembuatnya, maka dengan menginterpretasikannya akan didapatkan pemahaman terhadap teks berdasarkan persepsi pembuatnya. Kegiatan menginterpretasi adalah proses yang bersifat triadik, yaitu tiga sisi yang saling berhubungan dan saling berdialektik. Ketiga sisi itu adalah teks kebijakan itu sendiri, pengalaman mental pembuatnya, dan subjek yang meginterpretasikannya (Palmer, 1980; Schmidt, 2010). Makna teks kebijakan dipahami melalui sejarah pembuatannya, sedangkan subjek yang menginterpretasikannya harus memasuki jiwa zaman ketika teks itu dibuat. Melalui kegiatan triadik tersebut dapat dipahami makna keseluruhan teks kebijakan melalui bagian-bagiannya dan makna bagian-bagiannya dapat dipahami berdasarkan makna keseluruhannya.

Teks kebijakan kepariwisataan yang diinterpretasi adalah UU 9/1990 tentang Kepariwisataan dan UU 10/2009 tentang Kepariwisataan. Teks kebijakan tersebut akan dikaji pada bagian yang mendasarinya, lalu dikaitkan dengan Pembukaan UUD 1945 yang berkaitan dengan tujuan nasional bangsa Indonesia dan beberapa pasal yang terkait. 


\section{HASIL DAN PEMBAHASAN}

Tujuan Nasional Bangsa Indonesia dalam Pembukaan UUD 1945

Proses penyusunan Pembukaan UUD 1945 tidak bisa dipisahkan dari proses penyusunan UUD 1945 yang prosesnya berawal dari janji Jepang untuk memberikan kemerdekaan bagi bangsa Indonesia di kelak kemudian hari. Janji itu kemudian disikapi dengan pembentukan BPUPKI (Badan Penyelidik Usaha Persiapan Kemerdekaan Indonesia) pada 29 April 1945 yang melakukan sidang-sidangnya pada 29 Mei 1945 - 16 Juni 1945. Selanjutnya dibentuk Panitia 9 yang bertugas merumuskan pembukaan konstitusi yang kemudian disebut Piagam Jakarta. Pada tanggal 18 Agustus Piagam Jakarta disahkan menjadi Pembukaan UUD 1945 bersamaan dengan pengesahan UUD 1945 menjadi dasar negara Republik Indonesia oleh PPKI (Panitia Persiapan Kemerdekaan Indonesia).

Dalam Pembukaan UUD 1945 dinyatakan secara eksplisit dan implisit tujuan nasional bangsa Indonesia. Secara eksplisit, terdapat empat tujuan, yaitu melindungi seluruh rakyat Indonesia dan seluruh tumpah darah Indonesia; memajukan kesejahteraan umum; mencerdaskan kehidupan bangsa; dan turut serta melaksanakan ketertiban dunia yang berdasarkan kemerdekaan, perdamaian abadi, dan keadilan sosial. Makna tujuan pertama adalah seluruh bangsa Indonesia harus dilindungi dalam kehidupannya. Hal-hal yang termasuk harus dilindungi adalah semua komponen yang membentuk bangsa Indonesia, yaitu rakyat, kekayaan alam, dan juga nilai-nilai bangsa. Makna tujuan kedua adalah masyarakat Indonesia harus sejahtera, baik lahir, batin, dan juga materi, seperti terciptanya rasa aman, gotong royong, saling menghormati dan menghargai hak dan kewajiban masing-masing individu, keadilan, kesetaraan, dan kemakmuran. Makna tujuan ketiga adalah masyarakat Indonesia harus cerdas yaitu harus memperoleh kesempatan yang luas untuk mengenyam pendidikan yang layak dan berkualitas. Ketiga tujuan tersebut akan terlaksana bila dunia yang ditempatinya dalam keadaan tertib dan aman. Oleh karena itu, melalui tujuan keempat bangsa Indonesia bertekad untuk menjaga ketertiban dan keamanan di dunia tempat hidupnya. Semua itu dijalankan di dalam kerangka bangsa yang merdeka dan dalam suasana damai yang berkeadilan yang berlangsung terus menerus.

Selain yang eksplisit, tujuan nasional bangsa Indonesia juga terkandung secara implisit dalam Pembukaan UUD 1945. Bangsa Indonesia adalah keluarga dalam masyarakat dunia yang bertekad menjadi bangsa merdeka yang dapat mengatur nasib dirinya sendiri. Oleh karena itu, bangsa Indonesia tidak ingin dijajah, tetapi juga tidak ingin menjajah. Bangsa Indonesia mempunyai tekad kuat dan mampu untuk mengatur sendiri bangsanya. Bangsa Indonesia mempercayai kebaradaan Tuhan. Tekad itu diyakini akan mendapat perlindungan dan diridai Tuhan Yang Maha Kuasa, karena sejalan dengan ajaran kepercayaan apapun. Untuk mewujudkan tujuannya itu, bangsa Indonesia akan bersatu dan bersama-sama menjaga kedaulatannya, dengan menjaga rasa keadilan bersama untuk menuju kemakmuran bersama, sebagai sebuah keluarga besar bangsa Indonesia.

\section{Kondisi Politik Yang Melatarbelakangi}

Pembuatan Kebijakan Pembangunan Kepariwisataan

Dua undang-undang kepariwisataan dibuat pada kondisi politik yang berbeda. UU 9/1990 dibuat pada kondisi politik Demokrasi Pancasila yang dianut oleh Pemerintahan Soeharto. Demokrasi Pancasila berangkat dari suatu bentuk pemerintahan demokratis yang dasarnya adalah nilai-nilai yang terdapat pada bangsa Indonesia sendiri. Dasar formal dari jalannya demokrasi tersebut adalah UUD 1945 yang merupakan dasar negara Republik Indonesia. Semangat yang mendasari pembentukan dasar negara itu adalah persatuan untuk melepaskan diri dari penjajahan.

UUD 1945 disahkan menjadi undang-undang dasar Republik Indonesia pada 18 Agustus 1945. Dalam perkembangannya, undang-undang dasar negara Republik Indonesia pernah diganti oleh UUD RIS dan UUDS. Namun pada tahun 1959, dengan suatu Dekrit Presiden, UUD 1945 kembali digunakan oleh negara Republik Indonesia sebagai undang-undang dasarnya. Sejak saat itu, sampai jatuhnya Pemerintahan Suharto tahun 1998, UUD 1945 tetap dipergunakan sebagai undang-undang dasar Republik Indonesia, tanpa ada amandemen.

UU 10/2009 dibuat ketika Indonesia sedang dalam situasi demokrasi yang oleh beberapa pihak dikatakan sebagai "demokrasi yang sebenarnya". Peralihan haluan demokrasi ini dimulai tahun 1998. Ketika itu rakyat Indonesia yang tidak puas dengan Pemerintahan Suharto melakukan serangkaian demonstrasi di beberapa wilayah Indonesia. Beberapa demonstrasi itu mengarah pada kerusuhan-kerusuhan. Puncaknya terjadi pada pertengahan Mei 1998. Kerusuhan terjadi di mana-mana, sampai timbul penjarahan pada toko-toko yang dimiliki oleh kelompok masyarakat etnis Cina. Gedung DPR/MPR yang merupakan representasi dari rakyat Indonesia diduduki oleh kelompok mahasiswa. Pada 20 Mei 1998 Presiden Suharto mengundurkan diri sebagai Presiden Republik Indonesia dan digantikan oleh Wakil Presiden B.J. Habibie. Sejak itu bangsa Indonesia memasuki suatu era yang dinamakan era Reformasi.

Di era Reformasi, haluan politik Indonesia mengarah pada demokrasi seperti yang berjalan di beberapa negara barat. UUD 1945 diamandemen. Sepanjang era Reformasi telah dilakukan empat kali amandemen UUD 1945, yaitu: (1) Amandemen pertama disahkan 19 Oktober 1999; (2) Amandemen kedua disahkan 18 Agustus 2000; (3) Amandemen ketiga disahkan 9 November 2001; dan (4) Amandemen keempat disahkan 10 Agustus 2002. Inti amandemen yang pertama adalah mengatur kembali kekuasaan presiden yang dipandang terlalu kuat. Pada amandemen kedua intinya adalah perubahan pada pemerintah daerah, kewenangan DPR, hak asasi manusia, lambang negara, dan lagu kebangsaan. Inti amandemen ketiga adalah pada bentuk dan 
kedaulatan negara, kewenangan MPR, kepresidenan, impeachment, keuangan negara, dan kekuasaan kehakiman. Inti amandemen keempat adalah tentang DPD sebagai bagian dari MPR, penggantian presiden, pernyataan perang, perdamaian dan perjanjian, mata uang, bank sentral, pendidikan dan kebudayaan, perekonomian nasional dan kesejahteraan sosial, serta perubahan UUD (Sekretariat Jenderal MPR RI, 2011). Namun begitu, Pembukaan UUD 1945 tidak ada perubahan.

\section{Interpretasi Kebijakan Pembangunan Kepariwisataan}

UU 9/1990 terdiri dari sembilan bab 40 pasal, ditambah dengan penjelasannya yang merupakan suatu kesatuan dengan batang tubuhnya. UU 9/1990 yang dibuat pada masa Pemerintahan Suharto itu lebih banyak mengatur tentang kegiatan ekonomi di bidang pariwisata. Hampir tidak ada pasal yang mengatur hal lain di luar kegiatan ekonomi. Substansi yang diaturnya meliputi objek dan daya tarik wisata, usaha pariwisata, peran serta masyarakat, pembinaan, penyerahan sebagian urusan ke pemerintah daerah, ketentuan pidana, dan ketentuan penutup.

Dalam kaitannya dengan kegiatan ekonomi di bidang kepariwisataan itu, UU 9/1990 mengacu pada pasal 33 UUD 1945. Hal tersebut secara eksplisit dinyatakan dalam undang-undang tersebut. Pasal 33 UUD 1945 terdiri dari tiga ayat: Ayat 1 berbunyi "Perekonomian disusun sebagai usaha bersama berdasar atas asas kekeluargaan"; Ayat 2 berbunyi "Cabang-cabang produksi yang penting bagi negara dan yang menguasai hajat hidup orang banyak dikuasai oleh negara"; Ayat 3 berbunyi "Bumi dan air dan kekayaan alam yang terkandung di dalamnya dikuasai oleh negara dan dipergunakan untuk sebesar-besar kemakmuran rakyat". Dalam penjelasan pasal 33 UUD 1945 dinyatakan bahwa kemakmuran masyarakat harus diutamakan, bukan kemakmuran orang per orang. Hal itu berarti bahwa pembangunan ekonomi yang dijalankan harus dapat mensejahterakan seluruh rakyat Indonesia. Sehubungan dengan itu, cabang-cabang produksi yang penting harus dikuasai oleh negara. Apabila cabang-cabang produksi yang penting itu dikuasai oleh individu atau kelompok tertentu, maka rakyat Indonesia akan ditindas. Hal tersebut akan membawa kembali bangsa Indonesia ke masa penjajahan. Selain itu, pasal tersebut juga mengamanatkan bahwa dalam pembangunan ekonomi, masyarakat harus memegang peranan aktif. Kewajiban pemerintah hanya sebatas pada memberikan pengarahan dan bimbingan terhadap pembangunan ekonomi, serta menciptakan iklim yang sehat bagi perkembangan dunia usaha.

Pembangunan yang diinginkan UUD 1945 berada di tengah-tengah antara dominasi peran individu yang bebas dengan dominasi peran negara. Peran individu yang dominan akan menimbulkan eksploitasi, sedangkan peran negara yang dominan akan mematikan potensi dan daya kreasi masyarakat. Arah pasal 33 UUD 1945 itu menunjukkan kedaulatan bangsa Indonesia di bidang ekonomi. Bangsa Indonesia tidak ingin memihak pada negara-negara yang menganut paham liberal-kapitalis, tetapi tidak pula berpihak pada negara-negara yang berpaham sosialis-komunis. Kedua paham tersebut sedang bersaing di dunia internasional ketika penyusunan UUD 1945 sedang berjalan.
Bila diamati amanat pasal 33 UUD 1945 beserta penjelasannya, nampak bahwa negara menginginkan masyarakat Indonesia terlibat secara aktif dalam pembangunan ekonomi negaranya. Hal tersebut selaras dengan teori negara yang disampaikan oleh John Locke bahwa negara diciptakan karena suatu perjanjian kemasyarakatan antara rakyat dengan tujuan untuk melindungi hak milik, hidup, dan kebebasan, baik terhadap bahaya-bahaya dari dalam maupun bahaya-bahaya dari luar (Dryzek and Dunleavy, 2009; Budiman, 1996). Berdasarkan teori tersebut, negara mempunyai kewajiban untuk melindungi rakyatnya ketika sedang melakukan aktivitas pembangunan.

Keterlibatan secara aktif masyarakat di bidang pembangunan itu, berlaku juga bagi sektor pariwisata. Dengan mencantumkan pasal 33 UUD 1945 dalam UU 9/1990 menunjukkan bahwa pemerintah, yang dalam hal ini adalah Pemerintah Suharto, mengharapkan rakyat Indonesia terlibat aktif dalam pembangunan kepariwisataan, dan pemerintah siap untuk melindungi segenap rakyat Indonesia dari bahaya yang timbul ketika mereka melakukan aktivitas pembangunan di sektor kepariwisataan. Pembangunan kepariwisataan yang diharapkan adalah tidak memihak pada paham liberal-kapitalis yang berjiwa persaingan, tetapi juga tidak memihak pada paham sosialis-komunis yang menonjolkan dominasi negara yang mematikan kreativitas masyarakatnya. Pembangunan kepariwisataan diharapkan berangkat dari nilai-nilai bangsa Indonesia yang mengutamakan kekeluargaan dan gotong royong. Nilai-nilai tersebut menempatkan bangsa Indonesia dalam posisi yang aktif melakukan pembangunan kepariwisataan dengan dilandasi oleh nilai-nilai kekeluargaan yang saling membantu, saling mendukung, saling mengayomi, saling mengingatkan, saling menyayangi. Sistem ekonomi kekeluargaan melandasi kebijakan pembangunan kepariwisataan, seperti yang diatur dalam UU 9/1990.

UU 10/2009 yang terdiri dari 17 bab 70 pasal ditambah dengan penjelasannya dilahirkan atas dasar UUD 1945 yang sudah diamandemen. Adanya amandemen UUD 1945 ini menunjukkan bahwa telah terjadi perubahan haluan politik. Teori negara yang disampaikan oleh John Locke menjadi tidak relevan lagi untuk menjelaskan kondisi politik negara Indonesia karena kondisi politik di negara Indonesia telah dikuasai oleh kelompok tertentu yang menjadi kekuatan baru, yaitu partai politik. Kelompok itu telah memenangkan persaingan dalam suatu "permainan baru" yang diatur oleh UUD 1945 Amandemen. Hal tersebut menunjukkan bahwa telah terjadi perubahan fungsi negara dari yang berfungsi menjadi pelindung rakyatnya menjadi suatu wahana politik, tempat para elit masyarakat bersaing dan menunjukkan kekuatannya dalam masyarakat sebagai kelas penguasa. Hal tersebut selaras dengan apa yang dinyatakan Kaum Pluralis tentang teori negara. Kaum Pluralis mengajukan suatu teori yang disebut dengan Teori Negara Netral. Menurut teori ini, negara hanyalah sekadar wahana politik di mana kekuatan-kekuatan sosial yang ada di masyarakat saling ber- 
saing untuk menguasai negara. Kadang-kadang negara dikuasai oleh kelompok masyarakat tertentu, kadang-kadang kelompok lain yang berhasil menguasai birokrasi negara (Dryzek and Dunleavy, 2009; Budiman, 1996). Apabila negara dikuasai oleh kelompok tertentu, maka sangat logis bila negara melayani kepentingan kelompok tersebut. Namun, untuk melanggengkan kekuasaannya, maka negara yang dikuasai oleh kelompok tertentu itu perlu juga melayani kelompok lainnya supaya basis politiknya menjadi lebih luas. Hal tersebut berarti bahwa meskipun negara itu dikuasai oleh kelompok tertentu, tetapi kelompok penguasa itu harus juga bekerja untuk kepentingan yang lebih umum.

Substansi yang diatur dalam UU 10/2009 meliputi: hak dan kewajiban masyarakat; wisatawan; pelaku usaha; pemerintah dan pemerintah daerah; pembangunan kepariwisataan yang komprehensif dan berkelanjutan; koordinasi lintas sektor; pengaturan kawasan strategis; pemberdayaan usaha mikro, kecil, dan menengah di dalam dan di sekitar destinasi pariwisata; badan promosi pariwisata; asosiasi kepariwisataan; standardisasi usaha; kompetensi pekerja pariwisata; dan pemberdayaan pekerja pariwisata melalui pelatihan sumber daya manusia. Berdasarkan substansi itu, maka UU 10/2009 mengatur kegiatan pariwisata dari perspektif pembangunan ekonomi yang lebih luas bila dibandingkan UU 9/1990.

Berbeda dengan UU 9/1990 yang mencantumkan secara eksplisit pasal yang mengatur tentang perekonomian sebagai landasan undang-undang tersebut, dalam UU 10/2009 tidak dicantumkan secara eksplisit. Dalam UUD 1945 Amandemen, yang mengatur tentang perekonomian masih berada dalam pasal 33, seperti dalam UUD 1945 sebelum diamandemen. Namun ditambah dua ayat, sehingga menjadi lima ayat. Ayat keempat yang ditambahkan mengatur tentang perekonomian nasional yang berdasarkan asas demokrasi ekonomi dengan prinsip kebersamaan, efisiensi berkeadilan, berkelanjutan, berwawasan lingkungan, kemandirian dan keharusan untuk menjaga keseimbangan kemajuan dan kesatuan ekonomi nasional. Ayat kelima menyatakan tentang perekonomian nasional harus diatur oleh undang-undang. Kedua ayat yang ditambahkan ini diamandemen pada amandemen keempat tahun 2002. Dalam UU 10/2009 landasan undang-undang dasar yang dicantumkan hanya pasal 20 dan 21 UUD 1945. Pasal 20 UUD 1945 mengatur tentang fungsi DPR dalam membentuk undang-undang dan tentang pembentukan undang-undang. Pasal 21 mengatur tentang hak anggota DPR untuk mengajukan rancangan undang-undang.

Tidak dicantumkannya pasal 33 UUD 1945 sebagai landasan UU 10/2009 menunjukkan bahwa UU 10/2009 sangat fleksibel dalam mengadopsi perubahan ekonomi dunia. UU 10/2009 tidak kaku terikat pada keharusan untuk mengelola kepariwisataan atas asas kekeluargaan dan demokrasi ekonomi dengan prinsip kebersamaan. Semua pihak yang berminat untuk menyelenggarakan kepariwisataan dapat melakukannya di negara Indonesia. Investasi asing menjadi lebih mudah masuk dalam industri pariwisata di Indonesia. Pemerintah melindungi dan mendukung semua pihak yang terlibat dalam sektor kepariwisataan, tidak hanya sebatas pada warga negara Indonesia. Keadaan ini membawa pembangunan kepariwisataan Indonesia pada arus ekonomi dunia yang berlandaskan pada sistem ekonomi liberal-kapitalistik yang berjiwa persaingan bebas. Dengan tidak mencantumkan pasal 33 UUD 1945, UU 10/2009 akan semakin mudah dibawa pada sistem ekonomi tersebut.

UU 10/2009 memberi peluang besar untuk masuknya sistem ekonomi liberal-kapitalistik dan menyingkirkan sistem ekonomi kerakyatan yang digerakkan oleh dan untuk rakyat Indonesia sendiri. Dengan mengatasnamakan "pemenuhan kepuasan wisatawan" kapitalisme bisa masuk dan berkembang di Indonesia. Dengan mengatasnamakan "pemenuhan kepuasan wisatawan" pula, mereka yang memiliki modal besar akan menanamkan modalnya di suatu destinasi pariwisata dan menyingkirkan pemodal lokal yang memiliki modal kecil. Masyarakat lokal di suatu destinasi pariwisata hanya sebagai pegawai bagi pemodal besar atau bahkan hanya sebagai penonton di tempat tinggalnya sendiri. Mereka termarjinalkan oleh kegiatan kepariwisataan di tempat tinggalnya sendiri. Sudah banyak hasil kajian yang mengemukakan tentang termarjinalisasinya masyarakat lokal oleh pelaku usaha, baik oleh sesama bangsanya maupun bangsa asing, seperti kajian Abd. Karim (2008) di Lombok, Nyoman Sukma Arida (2009) di tiga desa di Bali, Nyoman Suryawan (2015) di Pulau Serangan Denpasar, Anak Agung Gde Bagus Udayana (2017) di Bali, dan Winengan (2019) di Lombok.

\section{SIMPULAN}

Berdasarkan pembahasan yang telah dikemukakan pada bagian sebelumnya, maka dapat disimpulkan bahwa kebijakan pembangunan kepariwisataan Indonesia seperti yang terwujud pada UU 9/1990 dan UU 10/2009 mengalami perubahan. Perubahan itu terjadi karena aturan yang mendasarinya, yaitu undang-undang dasar, mengalami perubahan. Pada kebijakan pembangunan kepariwisataan tahun 1990, paradigma yang mendasarinya adalah paradigma persatuan dan kekeluargaan. Paradigma tersebut erat kaitannya dengan semangat antipenjajahan dalam UUD 1945. Semangat tersebut dilatarbelakangi oleh kondisi yang sedang dalam suasana penjajahan ketika proses penyusunannya. Untuk mengusir penjajah diperlukan persatuan dengan landasan kekeluargaan yang saling membantu, saling mendukung, saling mengayomi, saling mengingatkan, dan saling menyayangi. Para pembuat UU 9/1990 masih dapat merasakan suasana penjajahan, sehingga mempengaruhi penyusunan undang-undang tersebut. Pada kebijakan pembangunan kepariwisataan tahun 2009, paradigmanya berubah menjadi paradigma persaingan bebas. Paradigma tersebut sejalan dengan UUD 1945 Amandemen yang cenderung dibawa ke arah liberalisme. Begitu pula para 
pembuatnya hidup dalam kondisi dan suasana persaingan dunia yang ketat dan sudah sangat jauh dari suasana penjajahan, sehingga terbawa pada penyusunan UU 10/2009.

Apabila dikaitkan dengan tujuan nasional bangsa Indonesia, seperti yang tersurat dan tersirat dalam Pembukaan UUD 1945, maka paradigma kebijakan pembangunan kepariwisataan tahun 1990 masih selaras dengan esensi tujuan itu. Esensi dari Pembukaan UUD 1945 adalah bangsa Indonesia yang sejahtera dan adil secara merata dalam kerangka keluarga besar bangsa Indonesia. Sebagai keluarga tentu akan mengedepankan saling menyayangi, saling membantu, saling mendukung, saling mengayomi, dan saling mengingatkan. Tidak saling mengalahkan, apalagi sampai menjatuhkan, karena hal itu akan menyakiti dan merugikan anggota keluarga lain yang dikalahkannya. Esensi tersebut terdapat dalam UU 9/1990 yang secara eksplisit mengemukakan asas kekeluargaan. Akan tetapi esensi itu pudar pada UU 10/2009, karena asas kekeluargaan digantikan dengan asas persaingan bebas, yang merupakan jiwa liberal-kapitalistik. Dengan begitu, maka kebijakan pembangunan kepariwisataan tahun 2009 telah berbelok menjauh dari paradigma tujuan nasional bangsa Indonesia.

\section{DAFTAR PUSTAKA}

Arida, N.S. (2009). Meretas Jalan Ekowisata Bali: Proses Pengembangan, Partisipasi Lokal, dan Tantangan Ekowisata di Tiga Desa Kuno Bali. Denpasar: Udaya University Press.

Birkland, T.A. (2016). An Introduction to the Policy Process: Theories, Concepts, and Models of Public Policy Making, ed.4. New York: Routledge.

Budiman, A. (1996). Teori Pembangunan Dunia Ketiga. Jakarta: Gramedia Pustaka Utama.

Cochran, C.E., et al. (2012). American Public Policy: An Introduction, ed.10. Boston: Wadsworth.

Damiasih dan Kusdarwati, H. (2016). Upaya Meningkatkan Kunjungan Wisatawan ke Sentra Industri Batik di Lendah Kulonprogo Yogyakarta. Jurnal Kepariwisataan, 10, (2), 41-46.

http://ejournal.stipram.ac.id/index.php/kepariwisataan/article/view/86

Dryzek, J.S. and Dunleavy, P.D. (2009). Theories of the Democratic State. New York: Palgrave Macmillan.

Dye, T.R. (2013). Understanding Public Policy, ed.14. Upper Saddle River: Pearson Education.

Junaid, I., et al. (2020). Pengelolaan Kampung Nelayan sebagai Desa Wisata di Kabupaten Majene, Sulawesi Barat. Pusaka: Journal of Tourism, Hospitality, Travel and Busines Event, 2, (1), 18-24.

https://ejournal-poltekparmks.ac.id/index.php/ pusaka/article/view/43

Karim, A. (2008). Kapitalisasi Pariwisata dan Marginalisasi Masyarakat Lokal di Lombok. Yogyakarta: Genta Press.
Nisbiatin, G. (2018). Relasi Sosial Pedagang dalam Pemanfaatan Hutan sebagai Wana Wisata (Studi Kasus Pedagang Warungan di Hutan Jati Goa Terawang di Desa Kedungwungu, Kecamatan Todanan, Kabupaten Blora), Solidarity, 7, (2), 408-420.

https://journal.unnes.ac.id/sju/index.php/solidarity/article/view/27985

Oktaviyanti, S.S. (2013). Dampak Sosial Budaya Interaksi Wisatawan dengan Masyarakat Lokal di Kawasan Sosrowijayan. Jurnal Nasional Pariwisata, 5, (3), 201-208.

https://journal.ugm.ac.id/tourism_pariwisata/article/view/6693

Palmer, R.E. (1980) Hermeneutics: Interpretation Theory in Schleiermacher, Dilthey, Heidegger, and Gadamer. Evanston: Northwestern University Press.

Qoriah, D., Ungkari, M.D., Muharam, H. (2019). Pengembangan Pariwisata Berkelanjutan Wisata Domba Adu di Desa Rancabango Tarogong Kaler Garut. Journal of Knowledge Management, 13, (2), 1-10. view/635

http://journal.uniga.ac.id/index.php/JKM/article/

Schmidt, L.K. (2010). Understanding Hermeneutics. Acumen: Durham.

Sekretariat Jenderal MPR R.I. (2011). Undang Undang Dasar Negara Republik Indonesia Tahun 1945. Jakarta.

Sumaryono, E. (1999). Hermeneutik: Sebuah Metode Filsafat. Yogyakarta: Penerbit Kanisius.

Suryawan, N. (2015). Alih Fungsi Pesisir Pascareklamasi dan Implikasinya terhadap Marginalisasi Nelayan di Pulau Serangan, Denpasar. Jurnal Kajian Bali, 05, (01), 57-80.

https://ojs.unud.ac.id/index.php/kajianbali/article/ view/15723

Udayana, A.A.G.B. (2017). Marginalisasi Ideologi Tri Hita Karana pada Media Promosi Pariwisata Budaya di Bali. Mudra: Jurnal Seni Budaya, 32, (1), 110-122.

https://jurnal.isi-dps.ac.id/index.php/mudra/ article/view/4

Waruwu, D., et al. (2020). Pengembangan Tanaman Herbal sebagai Destinasi Wisata di Desa Catur, Kintamani, Bali. Panrita Abadi, 4, (1), 1-10.

http://journal.unhas.ac.id/index.php/panritaabdi/ article/view/7668

Winengan. (2019). Local Community Resistance in Lombok Against Tourism Development Policy. Masyarakat, Kebudayaan dan Politik, 32, (1), 69-79.

http://e-journal.unair.ac.id/MKP/article/view/ 9279

Zed, M. (2008). Metode Penelitian Kepustakaan. Jakarta: Yayasan Obor Indonesia. 